\title{
EFFECT OF PEER TEACHING ON NURSING STUDENTS' PERFORMANCE OF CLINICAL TRAINING IN HEMODIALYSIS UNIT
}

\author{
Amal Eid Abdelmoniem Shaaban ${ }^{1}$, Tarek Mahmoud Shaker Mohamed ${ }^{2}$ \\ Lecturer of Medical-Surgical Nursing, Faculty of Nursing, Mansoura University ${ }^{1},{ }^{2}$
}

\begin{abstract}
Background: Peer teaching is considered as an effective educational approach for nursing students. It prepares them for their future roles as educators, enhances their psychomotor skills, attitudes, and builds their self-esteem. Aim: The study aimed to evaluate the effect of peer teaching on nursing students' performance of clinical training in hemodialysis unit. Design: A quasi experimental research design was utilized to achieve the aim of this study. The current study was carried out at the two hemodialysis units of Mansoura university hospital. A convenient sample of 74 of second level nursing students who were enrolled in Medical surgical nursing course. They were assigned randomly into study group (peer learners) who were exposed to peer teaching method (under researchers' observations) and control group (instructor learners) who were exposed to instructor teaching. Six students (peer teachers) were selected, had previous experience of the hemodialysis clinical area with satisfied performance score prior to study. Tools: Three tools were utilized; Interview questionnaire sheet, Performance Observational Checklist, and Acceptance \& satisfaction likert scales. Results: The results showed that there was no statistically significance difference between peer teaching group and control group regarding both of knowledge and performance concerning hemodialysis session termination. Conclusion: Peer teaching method can be used in clinical practice to overcome large numbers of students. Recommendations: Applying peer teaching method in clinical training. Also, it can be recommended to replicate the study in different clinical practice areas and large students' sample.
\end{abstract}

Key Words: Peer teaching; Students' Performance; clinical training. 


\section{INTRODUCTION}

Learning basic psychomotor nursing procedures is a major component of the clinical nursing curriculum, credit hour system, clinical training is often a stressful experience for students. Nursing clinical procedures are conducted in both the traditional classroom setting and the hospital setting (Brannagan et al., 2013).

Traditionally, clinical procedures are conducted using a modeling technique, in which the clinical instructor demonstrates the procedure at first then return demonstrations from students are applied. However, this method can impact on student's education and learning due to time constraints, and lack of student engagement (Gray, Wheat, Christensen \& Craft, 2018).

Over the past two decades, the learning environment in nursing clinical practice education has increased special concerns and attentions. Different learning models have been applied, one of which is peer teaching (Pålsson, Mårtensson, Swenne, Ädel \& Engström, 2017). Peer teaching means students acquire knowledge and skills from each other in the form of collaboration and has likely existed in higher education (Havnes, Christiansen, Bjørk \& Hessevaagbakke, 2016).

Peer teaching improves learners' active participation in clinical training and enhance competencies via interaction each other. It is also known as peer instruction, peer tutoring, and peer mentoring, and requires students to share knowledge, experiences, and ideas in a reciprocal manner (Dikmen et al., 2017).

Students are able to learn by sharing their ideas with their colleagues and by participating in activities in which they can learn from their peers. Peer teaching methods enhance students' self-learning experiences through the feedback from their peers which is effective in improving students' accountability and ability to acquire professional skills (Kang, Kim \& Choe, 2016).

Nowadays the clinical training skills becomes more complex; as it needs nursing education to respond properly by applying recent curriculum objectives plus encourage creative teaching strategies to prepare professional nursing graduates to meet the accelerating 
demands.(Zhang \& Cui, 2018). Peer teaching-learning may hold promise as a cost and learning effective method (Stone, Cooper \& Cant, 2013).

Furthermore, with the large students' numbers and financial costs on the universities, peer teaching method may resolve this issue as a cost-effective way to permit one-on-one attention, feedback and practice errors correction to junior while lowering demand on faculty(Vae, Kvalevaag \& Löfmark, 2017).

\section{Significance of the study}

Universities have utilized peer teaching facilitating learning for many years, but the teaching strategy is less common in nursing education (Arkan, Ordin \& Y1lmaz, 2018). Potential advantages of using peer teaching enhancing learning includes reducing student anxiety, increasing self-efficacy among nursing students, and providing a cost-effective method of education.

\section{AIM OF THE STUDY}

The study aimed to evaluate the effect of peer teaching on nursing students' performance of clinical training in hemodialysis unit.

\section{Hypothesis of the study:}

There would be no difference in the mean score between peer teaching group and clinical instructor group.

\section{SUBJECTS AND METHOD}

Study Design: quasi experimental research design was used.

Study setting: The present study was conducted at the two hemodialysis units of Mansoura university hospital. The main unit was a large hall with 21 hemodialysis machines within the Medical department (No.3). It had a special room for hemodialysis catheter insertion, a room for nurses, an office for head nurse, an office for doctors, a place for hand washing and bathrooms. The other unit near the neurological building had 7 hemodialysis machines, a room for nurses and a place for hand washing. The two units served three shifts; the morning shift started from 6 am to $11 \mathrm{am}$, the afternoon shift started from 11:30 am to 3:30 pm and the last one was from $4 \mathrm{pm}$ to $8 \mathrm{pm}$. The medical surgical nursing skill lab -Faculty of Nursing, 
Mansoura university was used to interview the six peer teachers students for orienting them about benefits of peer teaching and discussing their role.

Subjects: A convenient sample of (74) faculty of nursing students, Mansoura university $\left(2^{\text {nd }}\right.$ level, $4^{\text {th }}$ semester, academic year $2019-2020$ from $10^{\text {th }}$ February to $10^{\text {th }}$ March $)$ registered medical-surgical nursing course, who willing to participate in the study. Six students (peer teachers) were selected, had previous experience of the hemodialysis clinical area with satisfied performance score prior to the study.

Sample size: 74 nursing students

Sample size was statistically calculated by using the equation of Steven Thimpsone equation at $95 \%$ confidence power of the study, (Dawson-Saunders \& Trapp, 2001).

$$
\mathrm{N} \times \mathrm{P}(1-\mathrm{P})
$$

$\mathrm{n}=$

$(\mathrm{N}-1 \times(\mathrm{d} 2 / \mathrm{Z} 2))+\mathrm{P}(1-\mathrm{P})$

$\mathrm{n}=$ Sample size

$\mathrm{N}=$ Total society size (145 students)

$\mathrm{Z}=$ The corresponding standard class of significance $95 \mathrm{~d}=$ error percentage $=(0.05)$

$\mathrm{P}=$ percentage of availability of the character and objectivity $=(0.1)$

$\%=(1.96)$.

The sample size was calculated to be 74 students.

The total number of the $2^{\text {nd }}$ level, $4^{\text {th }}$ semester students was 580 students, divided into 4 equal groups, each group included 145 students.

The sample size was divided randomly into 2 equal groups; instructor group (37 students) and peer teaching group (37 students). Instructor group included the students who attended the clinical training with the clinical instructor directly, while, the peer teaching group included the students who attended the clinical training with their peer instructors (under the researchers'observations) 
Tools of the study: Three tools were used by the researchers to collect the necessary data to achieve the aim of the study.

\section{Tool I: Structured Interview:}

Part 1: Demographic data (age, gender) of the two groups.

Part 2: Hemodialysis questionnaire.

It was developed by the researchers to assess the students' knowledge regarding hemodialysis session, considering the review of literature (Levy, Brown, \& Lawrence, 2016; Albarran, Mallett, \& Richardson, 2013). It composed of 15 multiple choice questions (related to hemodialysis session duration, blood flow rate, arterial line, venous line, etc.).

\section{Scoring system:}

One degree was given for each correct answer and zero degree was given for missed answer or incorrect one, with total fifteen scores. The final score was obtained by weighting the sum of the correct responses relative to 15 . Higher scores indicated more knowledge.

\section{Tool II: Performance Observational Checklist:}

It was developed by the researchers to assess the performance of the students regarding hemodialysis session termination based on the recent literature review (Kallenbach, 2016) and it consisted of eight steps to be checked by the researchers.

\section{Scoring system:}

One degree was given for each accurately performed step and zero degree was given for missed step or inaccurate technique, with total eight scores. The final score was obtained by weighting the sum of the correct responses relative to 8 . Higher scores indicated the more skills.

\section{Tool III: Acceptance and satisfaction likert-type scales.}

It was composed of 20 items regarding satisfaction and acceptance with peer teaching. The responses to a four-point scale were; strongly disagree (1), disagree (2), agree (3) and strongly agree (4). Out of the twenty, 13 items were utilized to assess learner acceptance of the peer teaching method. These items were adopted from (Turner, Kitchenham, Brereton, Charters, \& Budgen, 2010), (Schepers \& Wetzels, 2007), and (King \& He, 2006), it was modified to make it suitable to the present study. Seven items were used to measure learner satisfaction with the peer teaching (Table 5). They were adopted and modified from those used by the (El-Sayed \& El- 
Sayed, 2013). The reliability of this scale was checked by (Donkor, 2011). These two scales were validated and high reliability were reported for each.

\section{Method.}

\section{Procedure intervention}

An official permission was obtained from the responsible authorities of Faculty of Nursing, Mansoura University after an explanation of the aim of the study.

\section{Pilot study}

A pilot study was carried out prior to data collection on 8 students $(10 \%)$ to test the tools for feasibility clarity, relevance, objectivity, and the applicability of them. Then the necessary modifications were done, students of pilot study were excluded from the sample.

\section{Ethical considerations:}

After explaining the aim of the study, consent was obtained from participant students and collected data would be confidential was assured. Participation in the study was entirely anonymity and voluntary. Refusal of participation in the study would not affect the students' degrees of achievement was also assured.

\section{Data collection Procedure}

- An interview was done by the researchers for the six peer teachers students for orienting them about the benefits of peer teaching and discussing their role. The interview was carried out in the medical surgical nursing skill lab -Faculty of Nursing, Mansoura University. It took about 4060minutes. They had the experience of the hemodialysis clinical rotation before, they were selected as they were knowledgeable and skillfully. Each one of them trained $6-7$ students (peer learners).

- All students of the study group exposed to peer teaching approach and control group exposed to instructor teaching approach, were interviewed. The researchers selected 1 clinical skill that should be learned in the clinical part of the hemodialysis rotation.

- Students of the study group were trained by the peer teachers students (under the researchers' observation)from 9 am to $2 \mathrm{pm}$ for 1 day/ week for two weeks. 
- Students of control group were trained by the faculty instructor of medical surgical nursing department from 9 am to $2 \mathrm{pm}$ for 1 day/ week for two weeks.

- The knowledge and the performance (Hemodialysis session termination) of students of both study and control groups were evaluated using part 2 of tool I and tool II (performance observational checklist). The Tool III was filled by the study group.

\section{Statistical analysis}

SPSS version 20 was used to analyze data. Independent t- test was used to check mean difference between the two groups.

\section{RESULT:}

Table (1): reports students' gender of study and control group. It is apparent that (64.9\%, $83.8 \%$ ) were females in the study group and control group, respectively.

Table (2): records students' knowledge about hemodialysis session. No significant difference between peer teaching group and control group regarding knowledge about hemodialysis session $(\mathrm{p}>0.05)$.

Table (3): presents students' performance concerning hemodialysis session termination procedure. No significant difference between peer teaching group and control group regarding students' performance concerning hemodialysis session termination $(\mathrm{p}>0.05)$.

Table (4): reports students' acceptance regarding peer teaching method. (78.4\%) of students described peer teaching as it added to their learning. Also, (64.9\%) described it as helped them to understand clinical procedures. (70.3\%) of the students recommend generalizing peer teaching method in the entire course. Finally, $(78.4 \%)$ of the students reported that peer teaching helped them to retain more information.

Table (5): shows students' satisfaction regarding peer teaching method. It shows that (75.7\%) of the students were satisfied about peer teaching method. (62.2\%) described it as more interesting method and helped them to spend more time in studying. 
Table (1): Percentage distribution of students' gender of study and control groups

\begin{tabular}{|l|c|c|c|c|}
\hline \multirow{2}{*}{} & \multicolumn{2}{|c|}{ Peer teaching group (37) } & \multicolumn{2}{c|}{ Clinical instructor group (37) } \\
\cline { 2 - 5 } & No & $\%$ & No & $\%$ \\
\hline Gender & 24 & 64.9 & 31 & 83.8 \\
-Female & 13 & 35.1 & 6 & 16.2 \\
- Male & & & & \\
\hline
\end{tabular}

Table (2): Students' knowledge about hemodialysis session

\begin{tabular}{|c|c|c|c|c|c|c|c|c|}
\hline \multirow{2}{*}{ Items } & \multicolumn{3}{|c|}{ Peer teaching group (37) } & \multicolumn{2}{c|}{ Clinical instructor group (37) } \\
\cline { 2 - 9 } & \multicolumn{2}{|c|}{ Incorrect } & \multicolumn{2}{|c|}{ Correct } & \multicolumn{2}{c|}{ Incorrect } & \multicolumn{2}{c|}{ Correct } \\
\cline { 2 - 9 } & No & $\%$ & No & $\%$ & No & $\%$ & No & $\%$ \\
\hline Red line & 4 & 10.8 & 33 & 89.2 & 2 & 5.4 & 35 & 94.6 \\
\hline Blue line & 3 & 8.1 & 34 & 91.9 & 2 & 5.4 & 35 & 94.6 \\
\hline Erythropoietin & 6 & 16.2 & 31 & 83.8 & 2 & 5.4 & 35 & 94.6 \\
\hline Heparin site & 8 & 21.6 & 29 & 78.4 & 6 & 16.2 & 31 & 83.8 \\
\hline Heparin time & 8 & 21.6 & 29 & 78.4 & 2 & 5.4 & 35 & 94.6 \\
\hline HD schedule & 4 & 10.8 & 33 & 89.2 & 2 & 5.4 & 35 & 94.6 \\
\hline Blood flow rate & 1 & 2.7 & 36 & 97.3 & 9 & 24.3 & 28 & 75.7 \\
\hline HD session & 0 & 0.0 & 37 & 100 & 1 & 2.7 & 36 & 97.3 \\
\hline Arterial line & 2 & 5.4 & 35 & 94.6 & 1 & 2.7 & 36 & 97.3 \\
\hline Venous line & 2 & 5.4 & 35 & 94.6 & 2 & 5.4 & 35 & 94.6 \\
\hline AV fistula & 1 & 2.7 & 36 & 97.3 & 2 & 5.4 & 35 & 94.6 \\
\hline AV graft & 1 & 2.7 & 36 & 97.3 & 5 & 13.5 & 32 & 86.5 \\
\hline HD catheter & 7 & 18.9 & 30 & 81.1 & 5 & 13.5 & 32 & 86.5 \\
\hline Blood sampling & 10 & 27 & 27 & 73 & 16 & 43.2 & 21 & 56.8 \\
\hline Thrill & 4 & 10.8 & 33 & 89.2 & 5 & 13.5 & 32 & 86.5 \\
\hline Mean \pm SD & & $28.35 \pm 2.13$ & & & $28.324 \pm 1.732$ \\
\hline Significance & & & $p=0.953$ & $t=0.060$ & & \\
\hline
\end{tabular}


Table (3): Students' performance concerning hemodialysis session termination procedure

\begin{tabular}{|l|c|c|}
\hline Skills & Peer teaching group (37) & Clinical instructor group (37) \\
\hline Mean \pm SD & $5.1 \pm 0.69$ & $5.23 \pm 0.74$ \\
\hline
\end{tabular}

Table (4): Students' acceptance regarding peer teaching method

\begin{tabular}{|l|c|c|c|c|c|c|c|c|}
\hline \multirow{2}{*}{\begin{tabular}{l} 
Items \\
\cline { 2 - 9 }
\end{tabular}} & \multicolumn{2}{|c|}{ Disagree } & \multicolumn{2}{c|}{$\begin{array}{c}\text { Strongly } \\
\text { Disagree }\end{array}$} & \multicolumn{2}{c|}{ Agree } & \multicolumn{2}{l|}{ Strongly Agree } \\
\cline { 2 - 9 } & No & $\%$ & No & $\%$ & No & $\%$ & No & $\%$ \\
\hline $\begin{array}{l}\text { added to the learning } \\
\text { content }\end{array}$ & 0 & 0.0 & 0 & 0.0 & 29 & 78.4 & 8 & 21.6 \\
\hline $\begin{array}{l}\text { help me understand } \\
\text { clinical procedures }\end{array}$ & 0 & 0.0 & 0 & 0.0 & 24 & 64.9 & 13 & 35.1 \\
\hline facilitated my learning & 0 & 0.0 & 0 & 0.0 & 19 & 51.4 & 18 & 48.6 \\
\hline $\begin{array}{l}\text { essential part of learning } \\
\text { topics }\end{array}$ & 0 & 0.0 & 0 & 0.0 & 25 & 67.6 & 12 & 32.4 \\
\hline $\begin{array}{l}\text { improve the learning } \\
\text { outcomes }\end{array}$ & 2 & 5.4 & 0 & 0.0 & 27 & 73 & 8 & 21.6 \\
\hline $\begin{array}{l}\text { Did not meet my } \\
\text { learning needs. }\end{array}$ & 16 & 43.2 & 11 & 29.8 & 6 & 16.2 & 4 & 10.8 \\
\hline a waste of time. & 15 & 40.5 & 16 & 43.2 & 3 & 8.1 & 3 & 8.1 \\
\hline $\begin{array}{l}\text { generalize the peer } \\
\text { teaching method }\end{array}$ & 7 & 18.9 & 1 & 2.7 & 26 & 70.3 & 3 & 8.1 \\
\hline $\begin{array}{l}\text { I learned as much in } \\
\text { peer teaching }\end{array}$ & 1 & 2.7 & 0 & 0.0 & 29 & 78.4 & 7 & 18.9 \\
\hline $\begin{array}{l}\text { More effective than } \\
\text { traditional method }\end{array}$ & 1 & 2.7 & 1 & 2.7 & 24 & 64.9 & 11 & 29.7 \\
\hline $\begin{array}{l}\text { Regularly used to teach } \\
\text { the whole course } \\
\text { contents }\end{array}$ & 1 & 2.7 & 2 & 5.4 & 22 & 59.5 & 12 & 32.4 \\
\hline $\begin{array}{l}\text { Retained more } \\
\text { information }\end{array}$ & 0 & 0.0 & 0 & 0.0 & 29 & 78.4 & 8 & 21.6 \\
\hline $\begin{array}{l}\text { Could fail in clinical } \\
\text { exams without peer } \\
\text { education }\end{array}$ & 7 & 18.9 & 3 & 8.1 & 26 & 70.3 & 1 & 2.7 \\
\hline
\end{tabular}


Table (5): Students' satisfaction regarding peer teaching method

\begin{tabular}{|l|c|c|c|c|c|c|c|c|}
\hline \multirow{2}{*}{ Items } & \multicolumn{2}{|c|}{ Disagree } & \multicolumn{2}{c|}{$\begin{array}{l}\text { Strongly } \\
\text { Disagree }\end{array}$} & \multicolumn{2}{c|}{ Agree } & \multicolumn{2}{c|}{$\begin{array}{c}\text { Atrongly } \\
\text { Agree }\end{array}$} \\
\cline { 2 - 10 } & No & $\%$ & No & $\%$ & No & $\%$ & No & $\%$ \\
\hline I am satisfied & 0 & 0.0 & 0 & 0.0 & 28 & 75.7 & 9 & 24.3 \\
\hline Enjoyable & 0 & 0.0 & 0 & 0.0 & 30 & 81.1 & 7 & 18.9 \\
\hline Acquire knowledge & 3 & 8.1 & 0 & 0.0 & 21 & 56.8 & 13 & 35.1 \\
\hline Students' performance & 0 & 0.0 & 0 & 0.0 & 22 & 59.5 & 15 & 40.5 \\
concerning hemodialysis & & & & & & & & \\
session termination & & & & & & & & \\
\hline More interesting & 1 & 2.7 & 1 & 2.7 & 23 & 62.2 & 12 & 32.4 \\
\hline Would rather & 10 & 27 & 6 & 16.2 & 18 & 48.6 & 3 & 8.1 \\
\hline More study & 1 & 2.7 & 0 & 0.0 & 23 & 62.2 & 13 & 35.1 \\
\hline
\end{tabular}

\section{DISCUSSION :}

Medical-surgical nursing has an important curriculum of education in which student nurses study diseases and proper nursing management and patient care. However, nursing students describe the curriculum as overloaded one because of the higher-order thinking procedures needed to master and connect the concepts.

Many researchers investigated the effects of peer teaching and found great benefits of this approach to all participant students. It enhances the development of self-confidence and reflective practice for peer teachers, while it can reduce anxiety and stimulate practice opportunities for peer learners (McKenna \&French, 2011).

Concerning sex, two thirds of the students was females. This result is in consistent with the result by Williams and Nguyen (2016) who explored that more than two thirds of their sample was females.

The current study result shows that no statistically significance noticed regarding mean practical score among nursing students trained by peer teaching method and students who trained 
by traditional method. Similar finding was reported by Rad, Yamani and Ehsanpour (2020) that the clinical skills score of students who trained via peer teaching was the same to traditional teaching. In contrast, Pålsson etal., (2017) reported that nursing students, learning in peers, rated improved learning and development. In addition to, Ahmad and Mohamed, (2018) indicate better performance scores among peer teaching group.

Regarding student's satisfaction, the study revealed that all nursing students who were trained by peer teacher were very satisfied, enjoyable; the majority of them acquired new skills. These results were similar to deMenezes and Premnath (2016) who reported that the student who were trained by peer teachers had gotten satisfied results; most of the learners enjoyed education, and the majority understood better the medical concepts and clinical skills. Moreover, Cheung and Wong, (2016) who reported that the students responded positively to the use of peer teaching and were satisfied with this interactive teaching and learning method.

Researchers' point of view, this is due to the support of peers and effective communication in the clinical environment has positive effects on students' learning. Moreover, a positive learning environment, clinical trainer supports. Also, the researchers trusted the students' attitude to conduct and finish the assigned tasks or seek for needed help. In this way, a confidential relation among both students and instructors facilitated and encouraged the educational process for the students.

The study results showed that the majority of peer teaching group reported that the peer teaching method helped them to acquire skills, similar result mentioned by $\mathbf{L i}$, Petrini and Stone, (2018) who reported that students regarded peers as an effective way of promoting knowledge acquisition. Our point of view, this is due to the students founded support from their colleagues, and nurses working at the place, they tolerated the advice from their colleagues. No stress and fear from the evaluation due to lack of experience and time limits.

The current study revealed that the peer teaching method described by the student as an effective, an essential section of education topics that based on imagination; help understand clinical procedures and, more effective than the traditional method of learning. This result was supported by Vuckovic, Karlsson and Sunnqvist, (2019), who mentioned that many nursing students described clinical training as a hard task, because of their poor of theoretical data and 
practical skills and poor communication with the preceptors. The researchers point of view, this back to gaining more knowledge and skills and the ability to share knowledge and skill without hesitancy or fear from the instructor supervision, no fear from doing mistakes which increased the chance to apply more skills and experience.

The peer teaching student group reported that the topics in peer teaching method facilitated learning; they wish if the peer teaching method regularly used to teach the entire curriculum contents. This finding was similar to Wareing et al., (2018) who mentioned that there were many educational chances for the students, where students accepted and tolerated the learning from their colleagues, could allow a wide range of opportunities for learning nursing.

Researchers' point of view, this due to low stress, relax environment for students, the fear and stress were replaced by a feeling of mindful and peaceful environment due to a strong and confidential relationship, mainly between colleagues, in addition to, even though the students might have wide range of learning styles regarding clinical practice, they could prefer finding a way work collaboratively and learning from each other`s differences.

\section{CONCLUSION \& RECOMMENDATIONS:}

Peer teaching method can be used in clinical practice to overcome large numbers of students. It can be recommended to apply the peer teaching method in the clinical training. Replicate the study in different clinical practice areas and large students' sample.

\section{REFERENCES:}

Ahmad, I.\& Mohamed, H.(2018). The effect of peer learning vs. traditional learning on knowledge and clinical performance of critical care nursing students. Journal of Education and Practice;9(8).

Albarran, J., Mallett, J. \& Richardson, A.(2013). Critical care manual of clinical procedures and competencies. Chichester, West Sussex: John Wiley \& Sons. 
Arkan, B., Ordin, Y. \& Y1lmaz, D.(2018). Undergraduate nursing students' experience related to their clinical learning environment and factors affecting to their clinical learning process. Nurse Education in Practice, 29, pp.127-132.

Brannagan, K., Dellinger, A., Thomas, J., Mitchell, D., Lewis-Trabeaux, S. \& Dupre, S.(2013). Impact of peer teaching on nursing students; perceptions of learning environment, selfefficacy, and knowledge. Nurse Education Today; 33(11), pp.1440-1447.

Cheung, M. \& Wong, J. (2016). The effect of peer instruction on promoting student nurses' learning in Medical-surgical Nursing. US-China Education Review A; 6(12).

Dawson-Saunders, B. \& Trapp, R. (2001). Basic \& clinical biostatistics. New York: Lange Medical Books/McGraw-Hill, Medical Pub. Division.

De Menezes, S. \& Premnath, D.(2016).Near-peer education; a novel teaching program. International Journal of Medical Education; 7, pp.160-167.

Dikmen, Y., Ak, B., Usta, Y., Ünver, V., Korhan, E., Cerit, B. \& Ertem, M.(2017). Effect of peer teaching used in nursing education on the performance and competence of students in practical skills training. International Journal of Educational Sciences;16(1-3), pp.14-20.

Donkor, F.(2011). Assessment of learner acceptance and satisfaction with video-based instructional materials for teaching practical skills at a distance. The International Review of Research in Open and Distributed Learning; 12(5), p.74.

El-Sayed, R. \& El-Sayed, S.(2013). Video-based lectures; an emerging paradigm for teaching human anatomy and physiology to student nurses. Alexandria Journal of Medicine; 49(3), pp.215-222.

Gray, S., Wheat, M., Christensen, M. \& Craft, J.(2018). Snaps; peer-to-peer and academic support in developing clinical skills excellence in under-graduate nursing students; an exploratory study. Nurse Education Today;73, pp.7-12. 
Havnes, A., Christiansen, B., Bjørk, I. \& Hessevaagbakke, E.(2016). Peer learning in higher education; patterns of talk and interaction in skills centre simulation. Learning, Culture and Social Interaction;8,pp.75-87

Kallenbach, J.(2016). Review of hemodialysis for nurses and dialysis personnel( $\left({ }^{\text {th }}\right.$ ed.), St. Louis: Elsevier/Mosby.

Kang, H., Kim, M. \& Choe, H.(2016). Effects of integrated nursing practicum by applying simulation-problem based learning on critical thinking disposition; nursing process competence and self-confidence on core basic nursing skills. Korean Association For LearnerCentered Curriculum And Instruction; 16(12), pp.495-508.

King, W. \& He J.(2006). A meta-analysis of the technology acceptance model. Inform Manage;43(6):740-55.

Levy, J., Brown, E. \& Lawrence, A.(2016). Oxford handbook of dialysis. New York, NY: Oxford University Press.

Li, T., Petrini, M. \& Stone, T. (2018). Baccalaureate nursing students' perspectives of peer tutoring in simulation laboratory, a Q methodology study. Nurse Education Today; 61, pp.235-241.

McKenna, L. \& French, J.( 2011). A step ahead; teaching undergraduate students to be peer teachers. Nurse Education in Practice;11(2), pp.141-145.

Pålsson, Y., Mårtensson, G., Swenne, C., Ädel, E. \& Engström, M. (2017). A peer learning intervention for nursing students in clinical practice education; a quasi-experimental study. Nurse Education Today; 51, pp.81-87.

Rad, R., Yamani, N. \& Ehsanpour, S. (2020). Effects of teacher-centered teaching and peer teaching methods on improving some clinical skills of midwifery students; a comparative study. [online] Ijme.mui.ac.ir. Available at: http://ijme.mui.ac.ir/article-1-4233-en.html [Accessed 2 Mar. 2020]. 
Schepers, J. \& Wetzels, M.(2007). A meta-analysis of the technology acceptance model; investigating subjective norm and moderation effects. Information \& Management;44(1), pp.90103.

Stone, R., Cooper, S. \& Cant, R.(2013). The value of peer learning in undergraduate nursing education; a systematic review. ISRN Nursing; pp.1-10.

Turner, M., Kitchenham, B., Brereton, P., Charters, S. \& Budgen, D.(2010). Does the technology acceptance model predict actual use? A systematic literature review. Information and Software Technology;52(5), pp.463-479.

Vae, K., Vae, K., Kvalevaag, H. \& Löfmark, A.(2017). Nursing students' perceptions of peer learning as a learning model in clinical practice and students' learning through peer learning; an evaluation study. Nordisk tidsskrift for helseforskning;13(2).

Vuckovic, V., Karlsson, K. \& Sunnqvist, C., (2019). Preceptors' and nursing students' experiences of peer learning in a psychiatric context; a qualitative study. Nurse Education in Practice; 41, p.102627.

Wareing, M., Green, H., Burden, B., Burns, S., Beckwith, M., Mhlanga, F. \& Mann, B.(2018). "Coaching and peer-assisted learning" (C-PAL) - The mental health nursing student experience; a qualitative evaluation. Journal of Psychiatric and Mental Health Nursing; 25(8), pp.486-495.

Williams, B. \& Nguyen, D.(2016). Near-peer teaching in paramedic education; a repeated measures design. Innovations in Education and Teaching International; 54(4), pp.345-354.

Zhang, J. \& Cui, Q. (2018). Collaborative learning in higher nursing education; a systematic review. Journal of Professional Nursing; 34(5), pp.378-388. 


\section{تأثير تذريس الاقران على اداع طلبة التمريض للتدريب العملى بوحدة غسيل الكلى \\ أمل عيد عبد المنعم شعبان 1 ، طارق محمد شاكر محمد 2 \\ مدرس تصريض الباطنى والجراحى ، كلبة التصريض جامعة المنصورة 1,2}

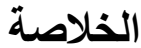

مقدمة: يعتبر تدريس الأقران بمثابة نهج تعليمي فعال لطلاب التمريض، فهى تعدهم لأدوار هم المستقبلية كمعمين ، وتعزز

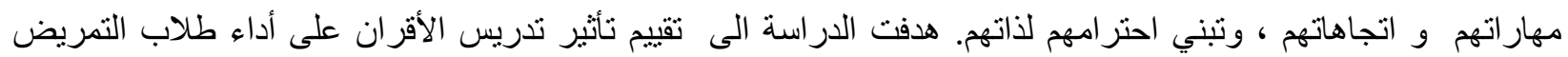
للتنريب العملى بوحدة غسيل الكلى. تصميم البحث: تم استخدام تصميم بحثي شبه تجريبي لتحقيق الهدف من هذه الدراسة. مكان اجراء الدراسة : أجريت هده الدراسة بوحدتى غسيل الكلى بمستشفى المنصورة الجامعى. عينة البحث: تكونت من 74 من طلاب تمريض المستوى الثاني المسجلين بمقرر التمريض الباطنى الجراحي. تم تقسيمهم بشكل عشوائي الى مجموعة الدر اسة (المتعلمين الأقران) الذين تعرضو ا لطريقة تدريس الأقران( تحت ملاحظة الباحثين) و المجمو عة الضابطة (المتعلمين بواسطة المدربين) الذين تعرضو التدريس المعلم. أدوات جمع البيانات: تم استخدام ثلاث أدوات وهم، الأداة الاولى عبارة عن استمارة استبيان وتكونت من جزأين ، الجزء الاول اشتمل على البيانات الدبموجر افية، و الجزء الثانى عبارة عن استمارة قياس معلومات الطلاب المتعلقة بجلسة الغسيل. الاداة الثانية وهى استمارة تقييم الأداء لتقييم اداء الطلاب للمهارة المختارة (إنهاء جلسة غسيل الكلى) .الاداة الثالثة : مقاييس القبول والرضا و تكونت من 20 عنصرًا متعلقًا بالقبول (مقياس قبول المتعلم) و الرضا (مقياس رضا المتعلم) عن تدريس الأقران، تم استخدام 13 بندًا لتقييم قبول المتعلم لطريقة تدريس الأقران. وتم تعديلها لجعلها تتناسب مع الدراسة الحالية. وسبعة عناصر لقياس رضا المتعلم العام عن تدريس الأقران ـ النتائج: أوضحت النتائج عدم وجود فروق ذات دلالة إحصائية بين مجموعة الدراسة ((المتعلمين الاقران) و المجموعة الضابطة فيما يتعلق بكل من المعلومات المتعلقة بجلسة غسيل الكلى و أداء الطلاب فيما يتعلق بإنهاء جلسة غسيل الكلى. أوضحت الدراسة أن معظم مجمو عة الدر اسة التي تم تدرييها عن طريق تدريس الأقران كانت راضية جدًا وقبولهم بطريقة تدريس الأقران. الكلمات المرشدة : تدريس الأقران؛ أداء الطلاب؛ التدريب العملى. 